\title{
OPTIMAL TUNING OF FUZZY LOGIC CONTROLLER PARAMETERS FOR INCREMENTAL CONDUCTANCE MPPT CONTROLLER BASED ON GREY WOLF OPTIMIZER ALGORITHM
}

\author{
Saied. A. Osman ${ }^{1}$, Rania. G. Mohamed ${ }^{1}$, Mohamed. A .Ebrahim ${ }^{2}$ \\ and Fahmy. A. Bendary ${ }^{2}$ \\ ${ }^{1}$ Department of Electrical Engineering-Faculty of Engineering - Al-Azhar University, Egypt \\ ${ }^{2}$ Department of Electrical Engineering -Faculty of Engineering at Shoubra-Benha University, Egypt
}

\begin{abstract}
Nowadays Maximum Power Point Tracking (MPPT) controller is considered the central part of any photovoltaic system to achieve the maximum power at all time under the change in weather conditions. MPPT techniques like, Perturb and Observe (P\&O), Incremental Conductance (IC) and Fractional Open-Circuit Voltage (FOCV) are the most commonly algorithm used due to low cost, easy implementation and simplicity. These algorithms are differing from each other according to sensors number, easy or complexity implementation and cost. The best algorithm is select according to accurate and fast tracking performance and minimum error due to changing conditions of weather. In this paper the optimal design for Incremental Conductance (IC) MPPT technique based on Fuzzy Logic controllers tuned by new optimization technique called Grey Wolf Optimizer (GWO) is applied for the largest PV project planned in Egypt. This PV project installed in Komombo, Aswan, Egypt and will have a total capacity of $20 \mathrm{MW}$. This study provides a comprehensive comparative study based on Average Power (A.P), transient behavior, Energy Availability (E.A) and Array Fill Factor (A.F.F) to choose the optimum control technique which is more suitable for controlling MPPT in Komombo PV power plant. MATLAB/SIMULINK is used to provide technical study and comprehensive analysis for the proposed PV power plant.
\end{abstract}

KEYWORDS: photovoltaic, Maximum power point tracking, Incremental Conductance, Fuzzy Logic Controller, Grey Wolf Optimizer.

\section{INTRODUCTION}

Egyptian energy demand is increasing every day and energy from conventional power station (fossil fuel) as well as energy from the high dam (hydro energy) does not able to satisfy this energy demand. Like other many countries, Egypt faces increasing challenges in the provision of energy services. Therefore, develop a comprehensive strategy for growth in the energy sector to cope with local market requirements becomes crucial. The strategy should consider many objectives. These objectives are; (1) how to achieve efficiency and sustainability and the reduction of carbon emissions, and the availability of energy resources, (2) competitive costs, and (3) the quality of existing networks and ways of energy transportation, as well as the extent to which this strategy, economic efficiency, and environmental sustainability [1]. Egypt, one of the states which lies inside the Sunbelt region and enjoy with the high direct solar radiation. So, it has become the Egyptian market a promising market in the field of solar energy especially, after the availability of modern technologies enable customers to rely on solar energy within the electricity network or outside it [2]. The installed capacity of Solar Energy Source (SES) in Egypt was about $1 \%$ of the total electricity production from 
Renewable Energy (RE) sources in March 2016 [1]-[3]. The solar power capacity has expanded rapidly to $305 \mathrm{GW}$ by the end of 2016 with a global growth rate of $52 \%$ which was higher than in 2015 (26\%) [4]. Solar energy production was around $25 \%$ of the global renewable generation capacity, and growing rapidly [4]. According to international statistics by 2030 photovoltaic (PV) technology growth will be reach $800 \mathrm{GW}$, this rapidly growth due to PV system does not even need to fuel [1]-[5]. Photovoltaic is one of the latest technology used in electrical power generation; it converts sunlight directly into electricity, it uses a semiconductor material such as silicon, which is the extract from pure sand 4]-[5]. Photovoltaic considered a form of renewable and clean energy because during the run it there is no contaminated waste, noise, radiation and do not even need to fuel. However, the cost of elementary high compared with other energy sources [5].The major advantage of photovoltaic that is not the moving parts exposed to malfunction.

\section{*Corresponding Author: Rania Gamal Mohamed}

E-mail address;eng_raniagamal_2013@yahoo.com

For this, it works over satellite with high efficiency, in particular, and they need no maintenance or repairs or fuel, where it operates in silence [6].The major problem with a photovoltaic system that is affected by the change in radiation and temperature, therefore, it is crucial to run it at maximum power point (MPP) to get the highest power from it [5]-[7].Nowadays Maximum Power Point Tracking (MPPT) system is considered the central part of any photovoltaic system to achieve the maximum power at all time under the change in weather conditions. There are many MPPT algorithms discussed in scientific research such as Incremental Conductance (IC), Fuzzy Logic Control (FLC), Artificial Neural Networks (ANN), Fractional Open-Circuit Voltage (FOCV), Sliding Mode Control (SMC), Particle Swarm Optimization (PSO), Perturb and Observe (P\&O), Fractional short-Circuit current (FSCC) [8]-[9]. However, these algorithms are differing from each other according to sensors number, easy or complexity implementation and cost. The best algorithm is select according to accurate and fast tracking performance and minimum error due to changing conditions of weather [10]. From all the mentioned algorithms, Incremental Conductance will introduce in this research work according to easy of implementations and low-cost [9]-[11]. Most of the researcher presented the Incremental Conductance (IC) maximum power point tracking algorithms based on Integral-controller as a classical MPPT algorithms, but this work offers a modified MPPT algorithms based on Fuzzy Logic Control (FLC),and Grey Wolf Optimizer (GWO) . The main problem of FLC controller is how to attain the optimum value of gains to achieve the best result. For this purpose, GWO technique is used to achieve the optimum gains of FLC controllers. The main contribution of this research work are summarized as the following:

- simulink model for $20 \mathrm{MW}$ PV solar power plant located at Komombo, Aswan, Egypt (Practical Case Study) is constructed.

- This research work proposed a modified MPPT techniques based on Fuzzy Logic controller using new optimization technique called GWO aiming to enhancing the transient stability of MPPT controllers.

- A comprehensive comparative study between the classical and the modified MPPT controllers is conducted to verify the effectiveness of the proposed GWO based Fuzzy Logic controller.

\section{PV module \& characteristics}

Figure.1 represent the equivalent circuit for Yingli Energy (China) YL305P-35b _PV module to express voltage-current (V-I) characteristic of this PV module [12]-[14].

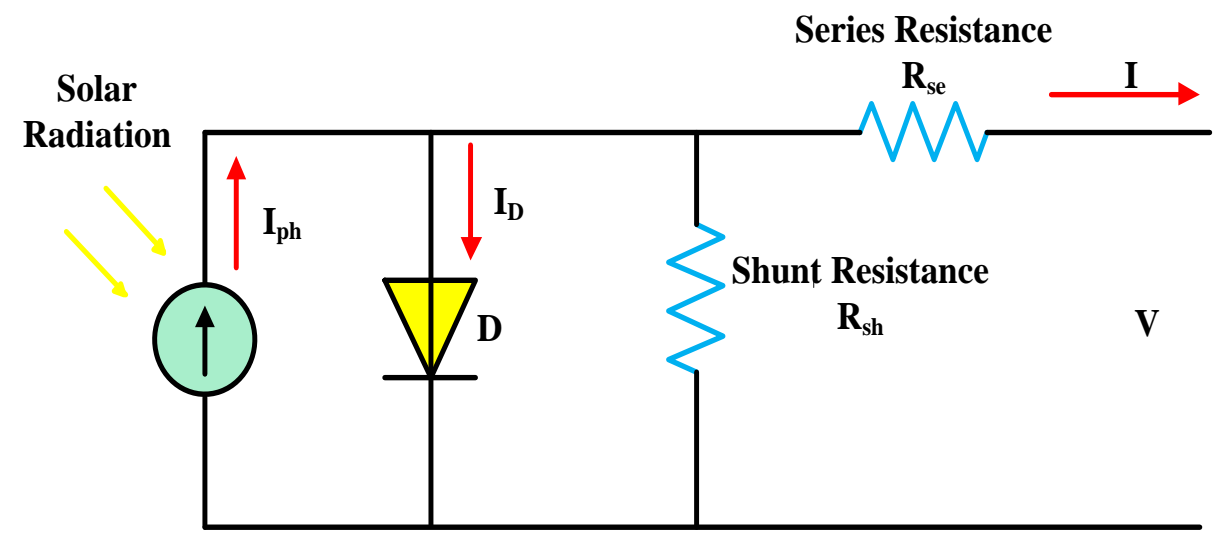


Figure .1: YL305P-35b_PV module equivalent circuit.

The values of PV module elements will be calculated using Matlab program developed by author. This developed program based on equations (1:11) which describe in the following section.

$$
\begin{aligned}
& \mathrm{I}=\mathrm{I}_{\mathrm{Ph}}-\left[\exp \left(\frac{V+\mathrm{IR}_{\mathrm{se}}}{\mathrm{aV} \mathrm{V}_{\mathrm{T}}}\right)-1\right]-\frac{\mathrm{V}+\mathrm{IR}_{\mathrm{se}}}{\mathrm{R}_{\mathrm{sh}}} \\
& \mathrm{V}_{\mathrm{T}}=\mathrm{n} \frac{\mathrm{KT}}{\mathrm{q}} \\
& I_{a s}=I_{a r}\left[\frac{T_{k}}{T_{r e}}\right]^{a} \exp \left\{\frac{\mathrm{qE}_{\mathrm{GO}}}{\mathrm{aK}}\left\{\frac{1}{\mathrm{~T}_{\mathrm{re}}}-\frac{1}{\mathrm{~T}_{\mathrm{k}}}\right\}\right\} \\
& \mathrm{I}_{\mathrm{L}}=\left[\mathrm{I}_{\mathrm{sct}}+\mathrm{K}_{\mathrm{i}}\left(\mathrm{T}_{\mathrm{cet}}-25\right)\right] \times \frac{\mathrm{H}}{1000} \\
& \mathrm{~T}_{\text {ce }}=\mathrm{T}_{\text {air }}+0.2 \times \mathrm{H} \% \\
& \mathrm{R}_{\mathrm{ge}}=\mathrm{A}\left[\omega_{-1}\left(\mathrm{Be}^{\mathrm{C}}\right)-(\mathrm{D}+\mathrm{C})\right] \\
& \mathrm{A}=\frac{\mathrm{aV}}{\mathrm{I}_{\mathrm{mpp}}} \\
& B=-\frac{V_{m p p}\left(2 I_{m p p}-I_{s c t}\right)}{\left(\left(V_{m p p} I_{s c t}\right)+V_{o c}\left(I_{m p p}-I_{s c t}\right)\right)} \\
& C=-\frac{2 V_{m p p}-V_{o c}}{a V_{T}}+\frac{\left(V_{m p p} I_{s c t}-V_{o c} I_{m p p}\right)}{\left(V_{m p p} I_{s c t}+V_{o c}\left(I_{m p p}-I_{s c t}\right)\right)} \\
& \mathrm{D}=\frac{\mathrm{V}_{\mathrm{mpp}}-\mathrm{V}_{\mathrm{oc}}}{\mathrm{aV} \mathrm{V}_{\mathrm{T}}} \\
& R_{s h}=\frac{\left(V_{m p p}-I_{m p p} R_{s e}\right)\left(V_{m p p}-R_{s e}\left(I_{s c t}-I_{m p p}\right)-a V_{T}\right)}{\left(V_{m p p}-I_{m p p} R_{s e}\right)\left(I_{s c t}-I_{m p p}\right)-a V_{T} I_{m p p}}
\end{aligned}
$$

Where,

I : YL305P-35b_PV module output current (A).

$V$ : YL305P-35b_PV module output voltage (V).

$\mathrm{I}_{\mathrm{ph}}$ : The photocurrent due to incident of solar irradiation (A).

$\mathrm{R}_{\mathrm{ge}}$ : The YL305P-35b_PV module series resistance $(0.44 \mathrm{ohm})$.

$\mathrm{R}_{\mathrm{sh}}$ : The YL305P-35b_PV module shunt resistance $(294.1069 \mathrm{ohm})$.

$\mathrm{V}_{\mathrm{T}}$ : The diode thermal voltage.

$\mathrm{K}$ : The constant of Boltzmann $\left(1.38 \times 10-23\right.$ joule $\left./{ }^{\circ} \mathrm{K}\right)$.

$\mathrm{q}$ : The charge of the electron $(1.602 \times 10-19$ coulomb).

$\mathrm{n}$ : The number of cells in series.

$\mathrm{T}$ : The normal temperature $\left({ }^{\circ} \mathrm{C}\right)$.

$\mathrm{I}_{\mathrm{Bs}}$ : The YL305P-35b_PV module reverse saturation current (A).

$\mathrm{I}_{\mathrm{ar}}$ : The reverse saturation current of the cell $(19.97 * 10-6 \mathrm{~A})$.

$\mathrm{T}_{\mathrm{k}}$ : The temperature of the cell in Kelvin $\left({ }^{\circ} \mathrm{K}\right)$.

$\mathrm{T}_{\mathrm{re}}$ : The reference temperature $\left(301^{\circ} \mathrm{K}\right)$.

a : The ideality factor (1.92).

$\mathrm{E}_{\mathrm{GO}}$ : The energy band gap of silicon (1.11 e.v).

$\mathrm{I}_{\mathrm{L}}$ : The YL305P-35b_PV module light generated current (8.8857 A).

$\mathrm{I}_{\text {sct }}$ : The YL305P-35b module short-circuit current at standard test condition $(8.87 \mathrm{~A})$.

$\mathrm{K}_{\mathrm{i}}$ : The coefficient of short-circuit current at certain temperature $\left(0.047001 \mathrm{~A} /{ }^{\circ} \mathrm{C}\right)$.

$\mathrm{T}_{\mathrm{ce}}$ : The temperature of the cell in Celsius $\left({ }^{\circ} \mathrm{C}\right)$.

$\mathrm{H}$ : The radiation incident on the cell $(\mathrm{W} / \mathrm{m} 2)$.

$\mathrm{T}_{\text {air }}$ : The air temperature $\left({ }^{\circ} \mathrm{C}\right)$.

$\mathrm{I}_{\mathrm{mpp}}$ : The YL305P-35b_PV module operating current at its maximum power point.

$\omega_{-1}$ : The expression of Lambert W-function [ W $\left.(\mathrm{z})\right]$, where $\mathrm{z}=W(\mathrm{z}) \mathrm{eW}(\mathrm{z})$. 
$V_{o c}:$ The YL305P-35b_PV module open circuit voltage at standard test condition.

$V_{\operatorname{mpp}}$ : The YL305P-35b_PV module output voltage at its maximum power point.

The electrical parameters of the YL305P-35b_PV module using the author developed Matlab program are giving in Table.1.

Table.1: Electrical parameters of the YL305P-35b_PV module.

\begin{tabular}{|l|c|}
\hline Electrical Parameter & Rating \\
\hline Light generated current $: \mathrm{I}_{\mathrm{L}}$ & $8.8857 \mathrm{~A}$ \\
\hline & $3.8623 \mathrm{e}^{-10} \mathrm{~A}$ \\
\hline Reverse saturation current $: \mathrm{I}_{\mathrm{gs}}$ & $0.44 \mathrm{ohm}$ \\
\hline Series resistance $: \mathrm{R}_{\text {se }}$ & \\
\hline & $294.1069 \mathrm{ohm}$ \\
\hline Shunt resistance $: \mathrm{R}_{\text {sh }}$ & \\
\hline
\end{tabular}

Figure. 2 shows the dynamic response of current and power against voltage variation for the simulated YL305P-35b_PV module at standard test condition.
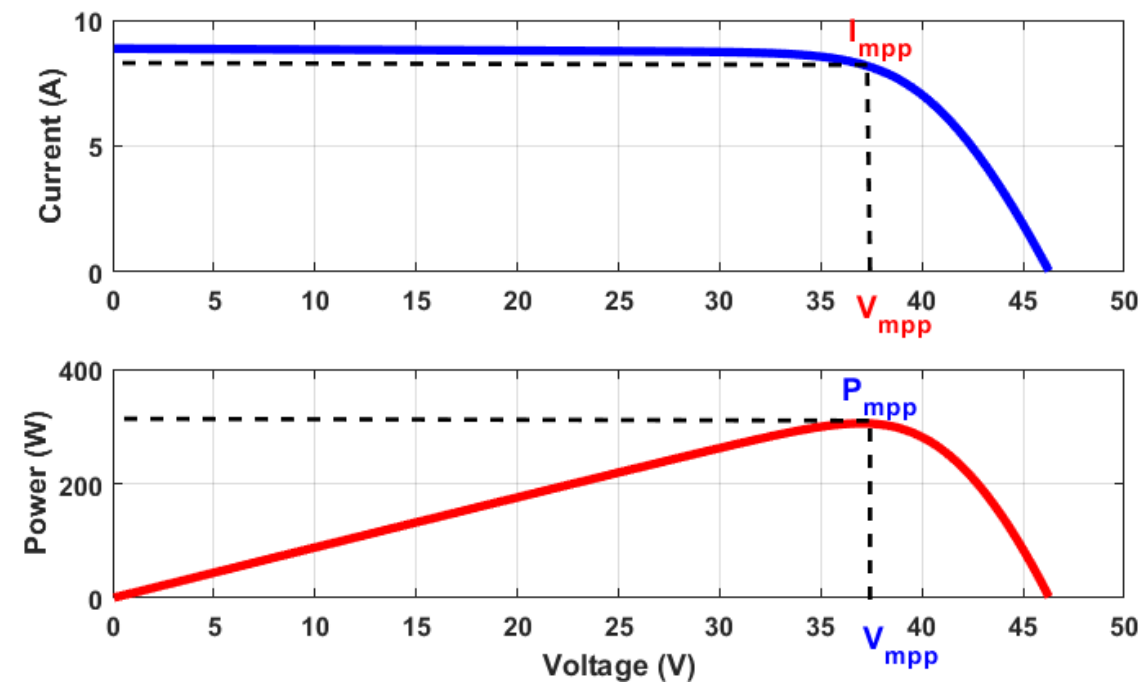

Figure.2. Simulated YL305P-35b_PV module Current \& Power at S.T.C.

\section{INCREMENTAL CONDUCTANCE MPPT ALGORITHM}

MPPT is very major criteria for any solar power plant to achieve the highest possible amount of the productive capacity of electricity under different irradiance and temperature levels. Therefore, the most scientific research in the field of solar energy addressed the issue of MPPT and its various implementation methods. According to reliable implementation, high efficiency and low- cost, incremental conductance MPPT method will be used in this paper. Incremental Conductance MPPT (IC) technique depends on the position of YL305P-35b_PV module slope as shown in following equations. At maximum power point the slope is zero, on the left of maximum power point the slope is positive, and at the right of maximum power point the slope is negative [15]-[16].The most researches of IC MPPT disregarded zero division problem, which represents major problem and lead to stop the technique. This paper presents solution to avoid the zero division problem by inserting a tiny number instead of zero. 


$$
\left\{\begin{array}{l}
\frac{\mathrm{dP}}{\mathrm{dV}}=0, \text { at } \mathrm{MPP} \\
\frac{\mathrm{dP}}{\mathrm{dV}}>0, \text { left of } M P P \\
\frac{\mathrm{dP}}{\mathrm{dV}}<0 \text {, right of } M P P
\end{array}\right.
$$

Since,

$$
\begin{aligned}
& \frac{d P}{d V}=\frac{d(I V)}{d V}=I+V \frac{d I}{d V}=I+V \frac{\Delta I}{\Delta V} \\
& \left\{\begin{array}{l}
\frac{\Delta I}{\Delta V}=-\frac{I}{V}, \text { at MPP } \\
\frac{\Delta I}{\Delta V}>-\frac{I}{V} \text {, left of MPP } \\
\frac{\Delta I}{\Delta V}<-\frac{I}{V} \text {, right of MPP }
\end{array}\right.
\end{aligned}
$$

The major problem of Incremental Conductance MPPT (IC) technique, it has a relatively slow transient stability and dynamic response time [17]-[18]. Therefore, this work presents a new modified IC MPPT algorithms aimed to providing an improved dynamic response time as compared to the classical IC technique. This modified IC technique based on FLC control using GWO. The main function of Fuzzy logic controller is to eliminate or minimize error to help IC MPPT algorithm in transient stability enhancement. Error in IC MPPT algorithm estimated according to the following equation.

$$
\text { Error }=\frac{\Delta \mathrm{I}}{\Delta \mathrm{V}}+\frac{\mathrm{I}}{\mathrm{V}}
$$

Also, comparative analysis between a modified and classical techniques will be discussed to choose the best technique for Komombo PV solar plant. In this paper the classical IC technique mean the technique which based on Integer controller and Genetic Algorithm (GA). Figure. 3 shows flowchart of classical and modified IC MPPT algorithms.

\section{GREY WOLF OPTIMIZER (GWO) TECHNIQUE}

Grey Wolf Optimizer (GWO) is one of the latest artificial intelligence technologies existing in the field of the optimal solutions for the engineering problems. The GWO algorithm represents the relationship between grey wolves leader and its hunter in nature. Grey wolves group consists of four types such as delta, beta, alpha and omega which used for simulating the leadership hierarchy. There are three main steps of searching, hunting, encirclement and attacking the animals. The main contribution of using GWO in this work is to attain the optimum gains of Fuzzy Logic controller to minimize or eliminate the error. GWO algorithm for optimal gains of Fuzzy Logic controller done according to the following steps:

1- Initialize grey wolf population at random positions.

2- Set the maximum number of iterations to 100.

3- Start estimation of grey wolves location at iteration $=0$.

4-Calculate object function of wolves for each search agent.

5-Check the current iterations with respect to maximum iterations.

6-Check for the objective function with pre-specified tolerance

7- If the current iteration is equal maximum iterations stop the evaluation and get the optimum value of Fuzzy Logic controller (K1, K2, K3).

8 - If the current iteration is less than maximum iterations, update grey wolf location and calculate the new object function for all search agents.

Figure.4 shows the flow chart that describes steps of GWO algorithm. 


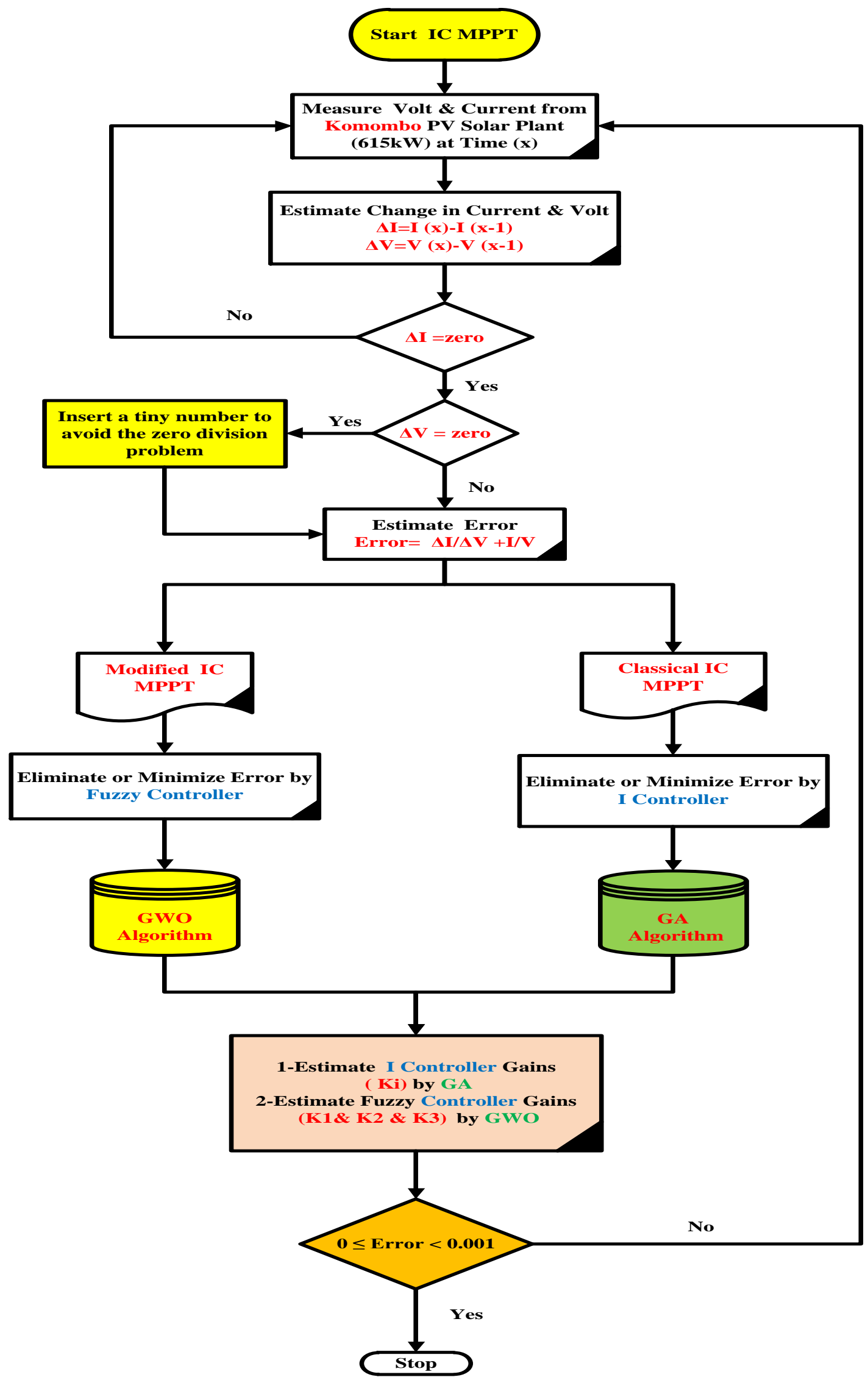

Figure.3: Classical \& modified IC flowchart. 


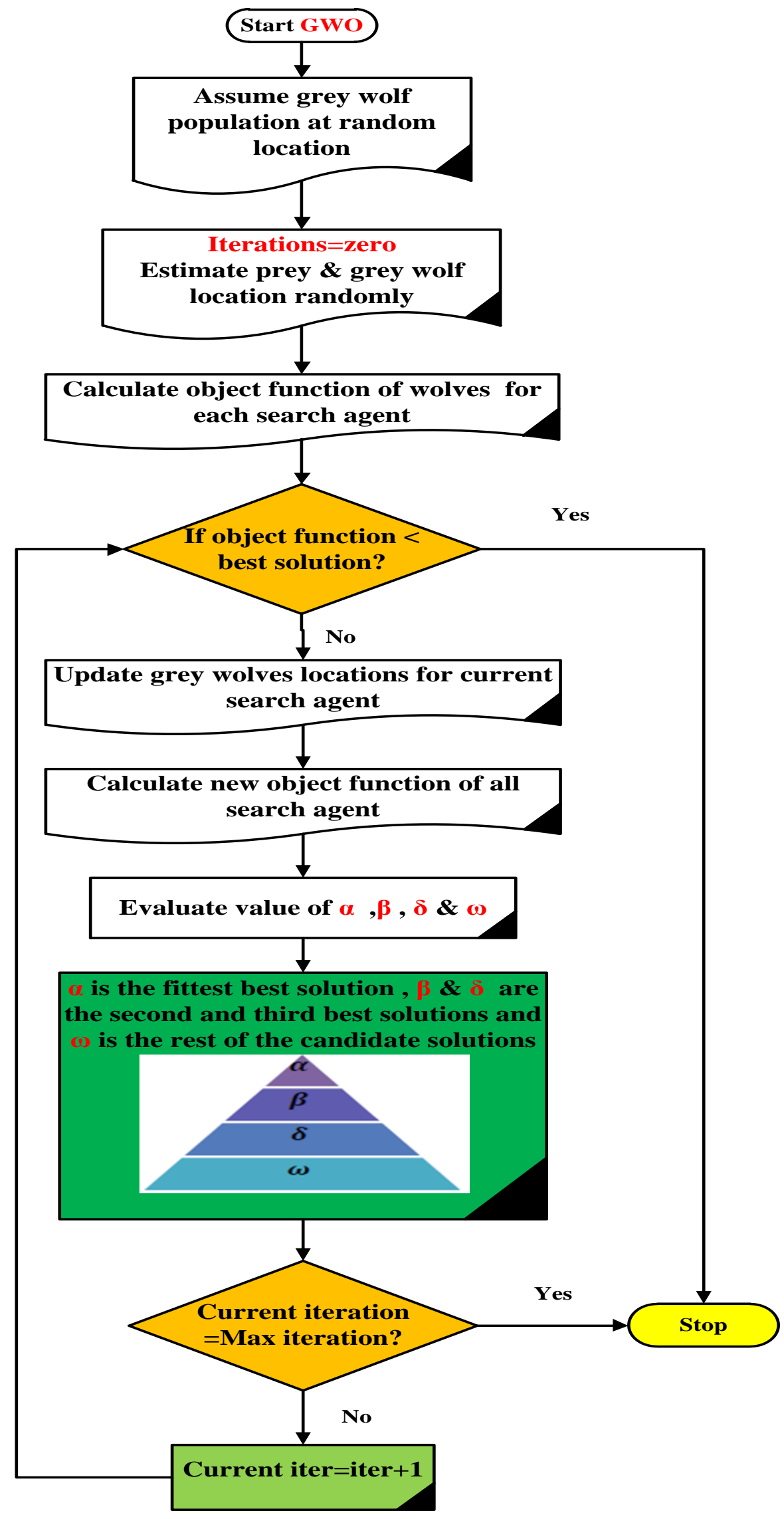

Figure.4: Flow-chart of GWO Algorithm. 


\section{SIMULATION RESULTS AND DISCUSSION}

According to author sizing, Komombo PV solar plant consists of 33 similar PV generators , each PV generator produced $615.3 \mathrm{~kW}$ with total power of $20 \mathrm{MW}$ for all PV generators. Komombo PV solar plant simulink model $(615.3 \mathrm{~kW})$ contain various simulation blocks such as PV array, three phase voltage source inverter (VSI), MPPT controller, a filter circuit, load, and utility grid. Figure.5 shows Komombo PV solar plant simulink model. PV array connected to an 11-kV network via a DC-DC boost converter and a three-phase three-level Voltage Source Inverter (VSI). In this paper, PV array generates a voltage of $666 \mathrm{~V}$ DC for a solar irradiance of $1000 \mathrm{~W} / \mathrm{m}^{2} .100-\mathrm{kHz}$ DC-DC boost converter increases the voltage from PV natural voltage (666 V DC at maximum power) to $825 \mathrm{~V} \mathrm{DC}$. Switching duty cycle is optimized by a MPPT controller that uses the 'Incremental Conductance + Fuzzy Logic Controller+GWO' technique. This MPPT system automatically varies the duty cycle in order to generate the required voltage to extract maximum power.

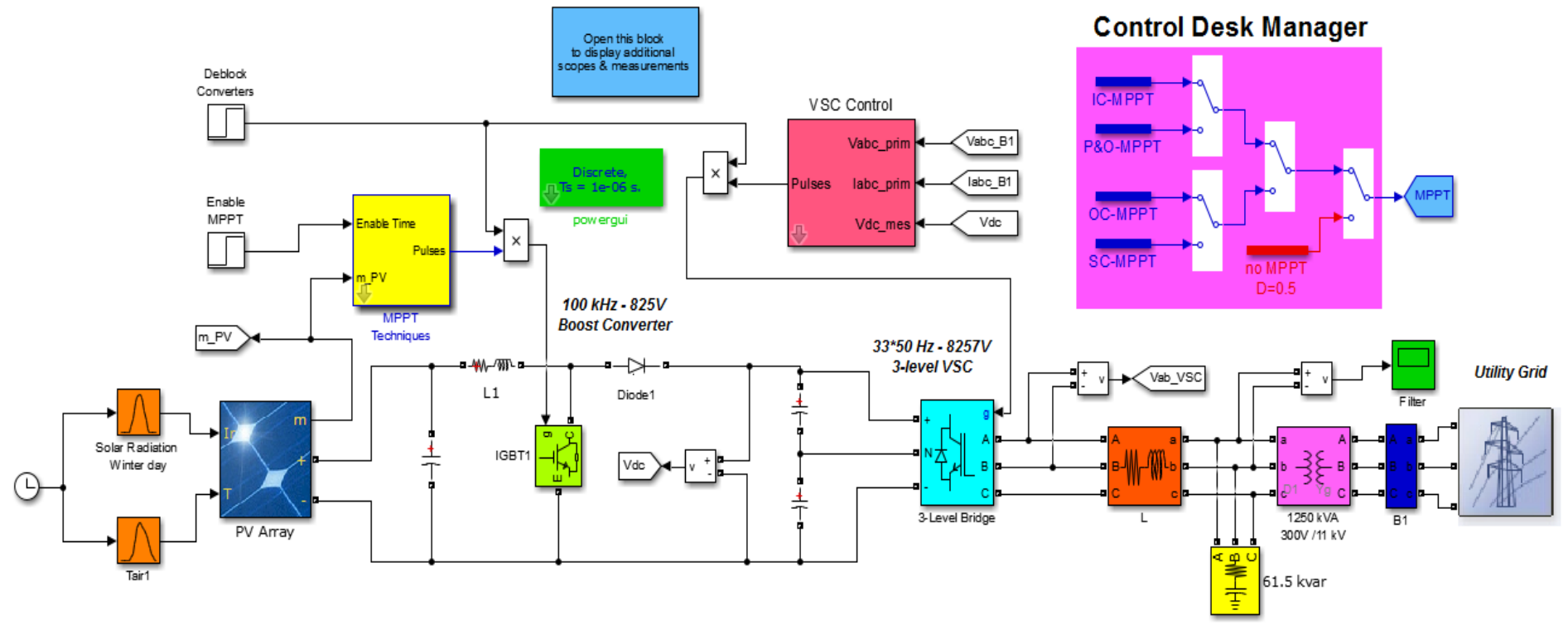

Figure.5. Komombo PV solar plant simulation system.

Comparison between MPPT algorithms needed to performance criteria to adjust each algorithm appropriately according to the application, so Average Power (A.P) , transient behavior, Energy Availability (E.A), and Array Fill Factor (A.F.F) are the four performance criteria for each MPPT algorithm. Komombo simulink model tested at realistic solar radiation and temperature for a winter day in the year as shown in Figure.6. After implementing the classical and modified IC MPPT algorithm on our simulink model. It can note that, modified IC which based on Fuzzy Logic Controller and GWO performs best results than classical IC which based on (I controller\& GA) according to the transient behavior response analysis as shown in Figure.7. Also, modified IC performs best results according to Average Power (A.P) Array Fill Factor (A.F.F) and Energy Availability (E.A) criteria as shown in Table.2. 1980-Hz 3-level 3-phase VSI converts the $825 \mathrm{~V}$ DC link voltage to $300 \mathrm{~V}$ AC and keeps unity power factor. The VSI control system uses two control loops: an external control loop which regulates DC link voltage to +/- $290 \mathrm{~V}$ and an internal control loop which regulates Id and Iq grid currents (active and reactive current components). Id current reference is the output of the DC voltage external controller. Iq current reference is set to zero in order to maintain unity power factor. $\mathrm{Vd}$ and $\mathrm{Vq}$ voltage outputs of the current controller are converted to three modulating signals Uabc_ref used by the PWM Generator. The control system uses a sample time of 100 microseconds for voltage and current controllers as well as for the PLL synchronization unit. Pulse generators of Boost and VSI converters use a fast sample time of 1 microsecond in order to get an appropriate resolution of 
PWM waveforms. There is 61.5-kvar capacitor bank filtering harmonics produced by VSI, $1250-\mathrm{kVA} 300 \mathrm{~V} / 11 \mathrm{kV}$ three-phase coupling transformer. Also, utility grid $(11-\mathrm{kV}$ distribution feeder $+120 \mathrm{kV}$ equivalent transmission system).
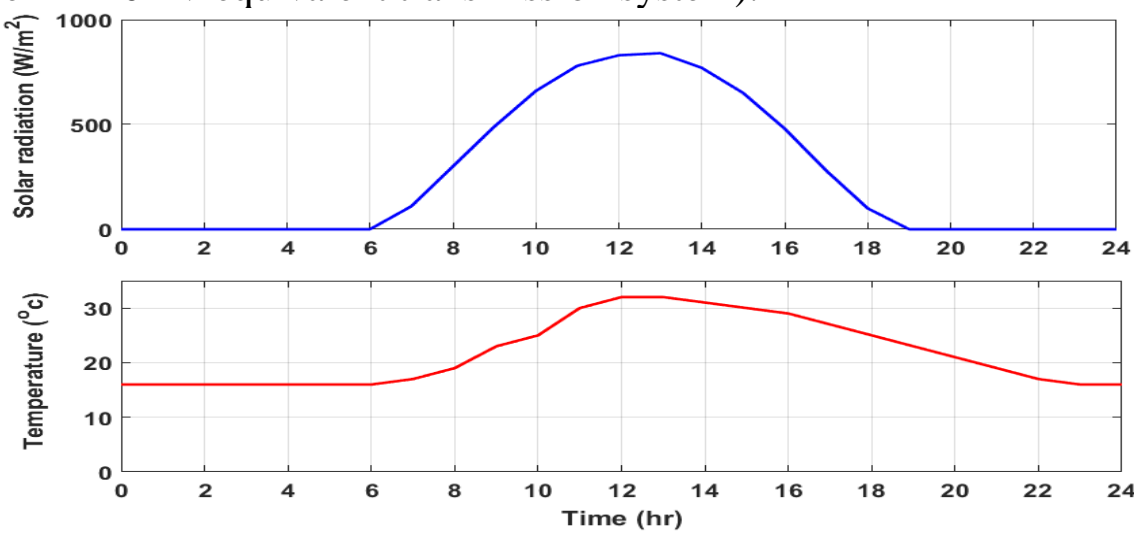

Figure. 6: The radiation and temperature waveform for winter day in the year at Komombo, Aswan, Egypt.

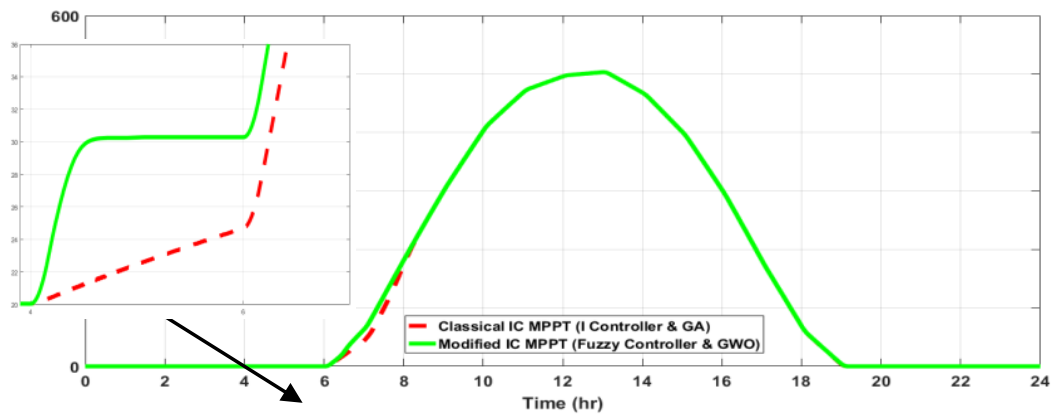

Figure.7: The output power for classical and modified IC with dynamic and transient responses for winter day in the year at Komombo, Aswan, Egypt.

Table. 2: A.P, A.F.F and E.A for classical and Modified IC MPPT algorithms

\begin{tabular}{|l|l|l|}
\hline & $\begin{array}{l}\text { Classical } \\
\text { IC }\end{array}$ & $\begin{array}{l}\text { Modified } \\
\text { IC }\end{array}$ \\
\hline Average Power $(\mathbf{k W})$ & 158.7952 & 161.9335 \\
\hline Array Fill Factor & 0.2580 & 0.2999 \\
\hline Energy Availability (kwh) & 381.1086 & 385.8406 \\
\hline
\end{tabular}

The optimal values of Fuzzy Logic controller gains using GWO shown in Table.3. The optimum gains of FLC controller achieved by Integral Time Square Error (ITSE). Results from Table.3 perform that modified IC has the lowest overshoot compared to classical IC. Also, the modified IC arrive to Maximum Power Point (MPP) faster than classical I.

Table 3: controllers gains for classical and modified IC using GWO.

\begin{tabular}{|c|c|c|}
\hline & $\begin{array}{c}\text { Classical IC } \\
\text { I Control +GA }\end{array}$ & $\begin{array}{c}\text { Modified IC } \\
\text { Fuzzy Control +GWO }\end{array}$ \\
\hline Ki & 7 & - \\
\hline K1 & - & 0.00698699 \\
\hline K2 & - & 8.89984 \\
\hline K3 & - & 0.0373718 \\
\hline Rise time $\boldsymbol{\mu}$ sec & 0.789 & 0.899 \\
\hline Settling time $\boldsymbol{\mu}$ sec & 1.0556 & 0.992 \\
\hline Maximum Overshoot & 1.055 & 0.932 \\
\hline
\end{tabular}

The comparative study showed that GWO is more efficient than GA in achieving MPPT because it has,

1- low number of iteration.

2-low computation time. 
3-high speed to reach the best solution.

\section{CONCLUSION}

4- and more stable.

This study presents a real PV solar power plant connected to the medium voltage distribution network (practical case study). This paper presents a new modified IC MPPT technique based on Fuzzy Logic Controller and GWO. The results confirm that modified IC technique is better than classical IC technique according to transient behavior, Energy Availability (E.A), and Array Fill factor (A.F.F). Also, the Fuzzy Logic Controller eliminated forced oscillations and steady state error resulting in enhancing of the dynamic behavior of the system as compared with the Integral Controller. This work proposed a new optimization algorithm inspired by grey wolves for determining optimal controller parameters. The results showed that GWO has the capability to provide highly competitive results compared to well-known Genetic Algorithm.

\section{REFERENCES}

[1] Egyptian State Information service (www.sis.gov.eg).

[2] International Agency for Renewable Energy (www.irena.org).

[3] Ministry of Electricity \& Energy New \& Renewable Energy Authority (NREA), Annual Report $2015 / 2016$.

[4] Ministry of Electricity \& Energy, New \&Renewable Energy Authority (NREA), Egyptian Solar Radiation Atlas, , Cairo, Egypt, 2005.

[5] International Atomic Energy Agency (ww.iea.org).

[6] World Energy Council (www.woldenergy.org).

[7] S. Sivasubramaniam, A. Faramus, R. D. Tilley, and M. M. Alkaisi, Performance enhancement in silicon solar cell by inverted nanopyramid texturing and silicon quantum dots coating, $\mathrm{J}$. Renewable Sustainable Energy 6, 011204 (2014).

[8] Nejib Hamrouni, Moncef Jraidi, Ahmed Dhouib, Adnen Cherif, " Design of a command scheme for grid connected PV systems using classical controllers", Electric Power Systems Research, Elsevier 143 (2017) 503-512.

[9] Hadjer Bounechba, Aissa Bouzid, Hamza Snani, Abderrazak Lashab, Real time simulation of MPPT algorithms for PV energy system, Electrical Power and Energy Systems, Elsevier. 83, (2016) 201-212.

[10] Mohammad Jangholi, Alireza Sedaghati, Design and Optimization of MPPT Routing in Solar Car Cells with the Maximum Power Point Tracking, International Journal of Advanced Research in Electrical, Electronics and Instrumentation Engineering, 5 (2016).

[11] Daniel Gonzalez Montoya, Carlos Andrés Ramos Paja, Roberto Giral, Maximum power point tracking of photovoltaic systems based on the sliding mode control of the module admittance, Electric Power Systems Research, Elsevier 136 (2016) 125-134.

[12] B. Pakkiraiah and G. D. Sukumar, A new modified MPPT controller for improved performance of an asynchronous motor drive under variable irradiance and variable temperature, International Journal of Computers and Applications, 6,(2016).

[13] M. A. Ebrahim, Tamer Elyan, Fady Wadie, and Mousa A. Abd-Allah., Optimal design of RC snubber circuit for mitigating transient overvoltage on VCB via hybrid FFT/Wavelet Genetic approach., Electric Power Systems Research, Elsevier 143 (2017) 451-461.

[14] M. A. Ebrahim ,H. A. AbdelHadi1, H. M. Mahmoud, Optimal Design of MPPT Controllers for Grid Connected Photovoltaic Array System, International Journal of Emerging Electric Power Systems, 17, (2016),511-517.

[15] M.E, Energy Storage Management in Grid Connected Solar Photovoltaic System, Journal of Engineering Research and Applications, 5, (2015),1-05.

[16] P Srinivas, K Vijaya Lakshmi, Ch Ramesh, Simulation of Incremental Conductance MPPT Algorithm for PV Systems using Lab View, International Journal of Innovative Research in Electrical, Electronics, Instrumentation and Control Engineering,4 (2016).

[17] Tey Kok Soon, Saad Mekhilef and Azadeh Safari, Simple and low cost incremental conductance maximum power point tracking using buck-boost converter, J. Renewable Sustainable Energy,5, 023106 (2013).

[18] Jiying Shi, Wen Zhang, Yongge Zhang, Fei Xue, Ting Yang, MPPT for PV systems based on a dormant PSO algorithm, Electric Power Systems Research, Elsevier 123 (2015), 100-107. 